\title{
The coming age of geriatric nephrology
}

\author{
Enyu Imai
}

Received: 9 August 2012/Accepted: 26 August 2012/Published online: 8 November 2012

(C) Japanese Society of Nephrology 2012

Baby boomers, aged around 60 years, and their children make two peaks in the demographic chart in Japan. The elderly population aged 65 and older comprised $17 \%$ of the population in 2010 and will be rapidly increasing to $30 \%$ by 2020 , mainly because baby boomers will reach the age of 65 years old and the birth rate will be low [1]. An aging society increases the prevalence of chronic kidney diseases (CKD). The number of patients with CKD was estimated to be about 13 million (13\% of the adult population) in Japan [2], and the incidence of end-stage kidney disease, which occurs at a mean age of 68 years, was more than 35,000 in the last 5 years [3]. The elderly population 70 years and older accounted for $58 \%$ of the CKD population [2]. The prevalence of proteinuria increases in association with aging, and 6.3 and $8.7 \%$ of the adult male population had proteinuria in their $70 \mathrm{~s}$ and $80 \mathrm{~s}$, respectively [2]. In females, individuals with proteinuria comprised 3.6 and $6.7 \%$, respectively [2]. Increasing numbers of elderly patients with kidney disease compel the field of geriatric nephrology to develop. However, limited data are available regarding pathological demographics in elderly patients. The Japanese Society of Nephrology launched the Japan Renal Biopsy Registry (JRBR) in 2007 to elucidate the pathological manifestation of Japanese renal diseases [4]. The registered biopsy record included more than 15,000 patients in 2012 and provided a great database resource for research [4].

This comment refers to the article available at doi:10.1007/s10157-012-0673-8.

E. Imai $(\bowtie)$

Nakayamadera Imai Clinic, 2-8-18 Nakayamadera,

Takarazuka, Japan

e-mail: ADS12069@nifty.com
On the basis of the JRBR, Yokoyama et al. [5] reported the largest renal biopsy registry for the elderly, defined as patients aged 65-79 years, and the very elderly, defined as 80 years and older. In the elderly patients, the indication for renal biopsy was a diagnosis of nephrotic syndrome, chronic glomerulonephritis or rapidly progressive glomerulonephritis. Chronic glomerular nephritis, mainly IgA nephropathy, was the leading cause of glomerular disease in the elderly, similar to the middle-aged patients. The indication for renal biopsy is similar to that for the younger generation. In contrast, more than $50 \%$ of biopsies were performed for the diagnosis of nephrotic syndrome, followed by rapidly progressive glomerulonephritis in the very elderly. The most frequent histological type in primary glomerular diseases was membranous nephropathy, followed by minimal change nephrotic syndrome, focal segmental glomerulosclerosis and IgA nephropathy. The difference in pathological manifestation in the very elderly may be the result of the indication for renal biopsy. Renal biopsy seems to be more carefully applied in the very elderly mainly because nephrologists consider renal biopsy only for making decisions about therapeutic options such as limited use of high-dose glucocorticoids and immunosuppressants in this group.

It is interesting that the pathological manifestation of nephrotic syndrome in the very elderly may be different between Japanese and American patients. Membranous nephropathy is the leading cause of primary nephropathy in the very elderly in Japan, while minimal change nephrotic syndrome (MCNS) has the highest incidence followed by focal segmental glomerulosclerosis (FSGS) according to a report from the USA [6]. Another report showed membranous nephropathy to be the most common, followed by MCNS [7]. The prevalence of benign nephrosclerosis associated with secondary FSGS is also high in the USA. 
The etiology of this pathological difference between the two countries needs to be elucidated. For example, the prevalence of the antibody against PLA2R might be different in patients with membranous nephropathy [8]. The prevalence of MPO-ANCA could be high in very elderly Japanese compared to British patients [9].

Another important message from the study is caution against using the urinary proteinuria/Cr ratio $(\mathrm{PCR})$ in the elderly. PCR is used as a substitution for measurement of 24-h urinary proteinuria because it is believed to be its equivalent. In the present study, the ratio of PCR over 24-h proteinuria increased according to aging: the PCR/24-h proteinuria ratios in the $70 \mathrm{~s}, 80 \mathrm{~s}$ and $90 \mathrm{~s}$ were $1.46,1.61$ and 1.90 , respectively, suggesting potential overestimation of PCR in the very elderly. The accuracy of the PCR is still unclear in very elderly patients. Many studies have shown a good correlation between random urinary PCR and 24-h protein excretion [10-12], while others have found it inaccurate and to be of limited use particularly in cases of heavy proteinuria $[13,14]$. Shortcomings of PCR are the presence of circadian rhythms and influence of diet. In addition, losing muscle mass, as often happens in elderly patients, also results in overestimation of PCR, leading to overdiagnosis of nephrotic syndrome. The ability of PCR to accurately predict 24 -h protein excretion is modest for monitoring protein excretion. Thus, given the limitations of PCR in the elderly and very elderly, a 24-h urine collection should be considered before making clinical decisions (e.g., biopsy) based on the presence of proteinuria. However, it is also true that there is some difficulty with 24-h urine collection in very elderly patients. In addition, further studies are needed to evaluate PCR concerning gender difference and changing body composition in the very elderly.

The present study elucidates new aspects of geriatric nephrology, but diagnosing and treating the very elderly remain apparently incomplete fields for medical professionals. Geriatric nephrology is coming of age, and the JRBR is expected to provide clues to open the way to the new age of geriatric nephrology.

\section{References}

1. http://www.mhlw.go.jp/toukei/saikin/hw/jinkou/kakutei10/ (Accessed, December 20, 2011).
2. Imai E, Horio M, Watanabe T, Iseki K, Yamagata K, Hara S, et al. Prevalence of chronic kidney disease in the Japanese general population. Clin Exp Nephrol. 2009;13:621-30.

3. http://www.mhlw.go.jp/toukei/saikin/hw/jinkou/kakutei10/ (Accessed, August 2, 2012).

4. Sugiyama H, Yokoyama H, Sato H, Saito T, Kohda Y, Nishi S, Tsuruya K, Kiyomoto H, Iida H, Sasaki T, Higuchi M, Hattori M, Oka K, Kagami S, Nagata M, Kawamura T, Honda M, Fukasawa Y, Fukatsu A, Morozumi K, Yoshikawa N, Yuzawa Y, Matsuo S, Kiyohara Y, Joh K, Taguchi T. Committee for Standardization of Renal Pathological Diagnosis and Working Group for Renal Biopsy Database, Japanese Society of Nephrology, Tokyo, Japan: Japan Renal Biopsy Registry: the first nationwide, web-based, and prospective registry system of renal biopsies in Japan. Clin Exp Nephrol. 2011;15(4):493-503.

5. Yokoyama H, Sugiyama H, Sato H, Taguchi T, Nagata M, Matsuo S, Makino H, Watanabe T, Saito T, Kiyohara Y, Nishi S, Iida H, Morozumi K, Fukatsu A, Sasaki T, Tsuruya K, Kohda Y, Higuchi M, Kiyomoto H, Goto S, Hattori M, Hataya H, Kagami S, Yoshikawa N, Fukasawa Y, Ueda Y, Kitamura H, Shimizu A, Oka K, Nakagawa N, Ito T, Uchida S, Furuichi K, Nakaya I, Umemura S, Hiromura K, Yoshimura M, Hirawa N, Shigematsu T, Fukagawa M, Hiramatsu M, Terada Y, Uemura O, Kawata T, Matsunaga A, Kuroki A, Mori Y, Mitsuiki K, Yoshida H. Renal disease in the elderly and the very elderly Japanese: analysis of the Japan Renal Biopsy Registry (J-RBR). Clin Exp Nephrol. 2012. doi:10.1007/s10157-012-0673-8.

6. Nair R, Bell JM, Walker PD. Renal biopsy in patients aged 80 years and older. Am J Kidney Dis. 2004;44:618-26.

7. Moutzouris DA, Herlitz L, Appel GB, Markowitz GS, Freudenthal B, Radhakrishnan J, D'Agati VD. Renal biopsy in the very elderly. Clin J Am Soc Nephrol. 2009;4:1073-82.

8. Beck LH Jr, Bonegio RG, Lambeau G, et al. M-type phospholipase A2 receptor as target antigen in idiopathic membranous nephropathy. N Engl J Med. 2009;361:11-21.

9. Fujimoto S, Watts RA, Kobayashi S, Suzuki K, Jayne DR, Scott DG, Hashimoto H, Nunoi H. Comparison of the epidemiology of antineutrophil cytoplasmic antibody-associated vasculitis between Japan and the U.K. Rheumatology (Oxford). 2011;50(10):1916-20.

10. Ginsberg JM, Chang BS, Matarese RA, Garella S. Use of single voided urine samples to estimate quantitative proteinuria. N Engl J Med. 1983;309:1543-6.

11. Steinhauslin F, Wauters JP. Quantitation of proteinuria in kidney transplant patients: accuracy of the protein/creatinine ratio. Clin Nephrol. 1995;43:110-5.

12. Brodby RA, Rohde RD, Zeev S, Pohl MA, Bain RP, Lewis EJ. The urine protein to creatinine ratio as a predictor of 24 hour urine protein excretion in type 1 diabetic patients with nephropathy. Am J Kidney Dis. 1995;26:904-9.

13. Lane C, Brown M, Dunsmuir W, Kelly J, Mangos G. Can spot urine protein/creatinine ratio replace $24 \mathrm{~h}$ urine protein in usual clinical nephrology? Nephrology (Carlton). 2006;11(3):245-9.

14. Wahbeh AM, Ewais MH, Elsharif ME. Comparison of 24-hour urinary protein and protein-to-creatinine ratio in the assessment of proteinuria. Saudi J Kidney Dis Transpl. 2009;20(3):443-7. 